\title{
How to Make Butter out of Guns: The Turkish Case and the Greek Bitter Lesson
}

\author{
Submitted 06/11/20, $1^{\text {st }}$ revision 22/12/20, $2^{\text {nd }}$ revision 20/01/21, accepted 17/02/21
}

\section{Dimitrios Doulos ${ }^{1}$, Odysseus Katsaitis ${ }^{2}$, George A. Zombanakis ${ }^{3}$}

\begin{abstract}
:
Purpose: This paper aims at assessing the links between defence expenditure and the growth of the Greek and Turkish economies. The issue appears to be of particular interest for Greece, given the increased defence priorities of today on the one hand, and the shortage of resources on the other.

Design/Methodology/Approach: Using NATO and SIPRI databases we construct a system of behavioural equations for both countries. We estimate the system using GMM to assess the extent to which the development of a domestic defence industrial base (DIB) will contribute to the growth of the economy, the reduction of unemployment via the spin-offs and the import substitution of defence equipment.

Findings: The results indicate that unlike the positive impact of the Turkish defence industry on economic growth, the cost imposed on the Greek economy due to the negligible contribution of its defence industry is hard to bear in view of the recent geopolitical developments in the Aegean and the Eastern Mediterranean.

Practical Implications: Promoting a sound defence industrial base contributes to growth. If the industrial base is considerably defence-oriented, contributes to self-sufficiency, immediate response in cases of emergency and less dependence on foreign suppliers.

Originality/Value: Unless Greece proceeds to an import-substitution policy regarding defence procurement, the increased requirements in view of the recent geopolitical developments will impose a prohibitive cost on the economy.
\end{abstract}

Keywords: Growth, defence spending, import substitution.

JEL codes: F45, H56, H60.

Paper type: Research article.

Acknowledgement: We are indebted to Ioanna Bardakas, Economist, Research Department, Bank of Greece, for valuable technical advice.

\footnotetext{
${ }^{1}$ Department of Accounting, Economics and Finance, The American College of Greece.

${ }^{2}$ Department of Accounting, Economics and Finance, The American College of Greece.

${ }^{3}$ Corresponding author, Department of Accounting, Economics and Finance, The American College of Greece, gzombanakis@acg.edu
} 


\section{Introduction}

National defence is a public good and consequently almost all categories of military expenditure burden the government budget. In Greece most of the military equipment is imported. This is due to the defence industrial base lying almost idle for several decades because of different reasons ranging from political interventions with management issues to bureaucracy impediments leading to waste of resources. Consequently, the Greek defence industry is now seriously lagging that of Turkey, a country with which Greece has been entangled in an arms race. As a result, the former is now able to support more than half of the country's defence requirements using domestic production. By contrast, Greece is compelled to import an overwhelming percentage of the defence equipment required with all multiple adverse repercussions that such a policy may entail on the security of the country, the availability of equipment in emergency cases, the balance of payments and the technology transfer.

As mentioned in the next section, the issues of defense spending and the development of the DIB in Greece has grown to becoming a debate in the literature approached in the light of mainly two perspectives, i. e. the country's recent poor economic performance and the escalating demands from the part of Turkey to revise the status-quo in the Aegean and the Eastern Mediterranean. During the Greek economic crisis, the European Commission (EC), the European Central Bank (ECB) and mainly the International Monetary Fund (IMF) had been insisting that defence procurement cuts must be a top priority ${ }^{4}$. This policy recommendation has been encouraged following the recent NATO summit, during which it has been pointed out that Greece is one of just five member countries that allocate $2 \%$ or more of their GDP to defence ${ }^{5}$. Considering the recent geopolitical developments and the fact that the Greek economy has been recovering - at least until the recent pandemic - the issue of an increase in defence spending has become more than pressing. The urgency of the matter is justified since all procurement programs of the Hellenic Armed Forces (EMPAE) have been cancelled or postponed during the crisis years. Such decisions solely based on economic grounds, however, endanger the effectiveness of the Hellenic Armed Forces in the recent volatile geopolitical environment. The result of these defense budget cuts has been the minimization of the contribution of the Hellenic Defence Industrial Base (DIB) to the EMPAE.

Consequently, Greece is doomed to rely more and more on importing expensive defence equipment to support the EMPAE requirements. An alternative for Greece

\footnotetext{
${ }^{4}$ In fact, the IMF has repeatedly expressed in the past its concerns on the issue of "excessive defence spending" (IMF, 2010, 2012 and 2014).

${ }^{5}$ This is a rather naïve approach concerning the issue of NATO members burden sharing, considering that in most cases about $70 \%$ of total defence spending reflects expenditure on personnel wages and salaries leaving only about 10 to $15 \%$ for equipment procurement.
} 
would be to proceed with an import-substitution policy concerning the production of selected defence equipment items for the Hellenic Armed Forces. This is an option encouraged by the findings in the literature. However, the importance of a Greek DIB has not been empirically assessed until now, despite the successful examples of neighboring countries like Turkey and Israel.

The purpose of this paper is to examine the contribution of such an industry on the performance of the economy. For this reason, we shall focus on the case of Turkey and Greece since the former's DIB performance has had a positive impact on its economy while the two countries are involved in lengthy arms race. The paper proceeds as follows: the next section presents a brief literature review followed by an outline of the Greek and Turkish defence industrial bases. Section 4 describes the methodology used to assess the contribution of a Defence Industrial Base (DIB) on the two countries' economic growth, while the next section presents the empirical results. Finally, section 6 deals with the policy implications before conclusions are drawn.

\section{Review of Literature}

The relevant literature offers a wide variety of definitions concerning the defence industrial base (DIB). The US Department of Defence e.g., defines DIB as the "Department of Defence, government and private sector worldwide industrial complex with capabilities to perform research and development, design, produce and maintain military weapon systems, subsystems, components, or parts to meet military requirements". (US DoD) ${ }^{6}$. By contrast, a more academic definition is proposed by Dunne, this being "a defence industrial base constitutes those companies which provide defence and defence related equipment to the defence ministry" (Dunne, 1995).

The so-called "Benoit hypothesis" concludes that defence spending promotes economic growth (Benoit, 1978). One of the channels through which defence expenditure contributes to economic growth is the performance of a sound DIB. The functions of a national DIB have been widely discussed in the literature and the dominant view seems to be that "a national defence industrial base offers both military-strategic and wider economic and industrial benefits" (Sandler and Hartley, 1995).

In assessing the impact of a DIB on economic performance, research focuses either on groups of countries, or individual country cases. Sandler and Hartley (2007) attempt a parallel consideration of the NATO and EU defence markets. They point

\footnotetext{
${ }^{6}$ Definition provided at: https://www.militaryfactory.com/dictionary/military-terms defined.asp?term id=1554. Accessed on January $25^{\text {th }}, 2020$.
} 
out that defence industries have the features of an "economically strategic industry as they are characterized by decreasing per unit costs reflecting economies of scale and learning, high technology reflected in major and costly $\mathrm{R} \& \mathrm{D}$, together with technical spillovers to the rest of the economy". Concerning individual country studies, Dunne and Haines (2002) focus on the case of the South African DIB and mention a number of channels through which a DIB can affect the economy positively or negatively, such as supporting jobs, crowding out civil sector investment or spinning off technology to the civil sector. Kuah and Loo (2004) find that in the case of Singapore, the link between the defence industrial base and economic growth is not clear. On one hand, the domestic DIB has delivered what the theory postulates: job creation, human capital development together with technology development and diffusion. On the other hand, such benefits have come largely because of the spectacular growth of the Singapore economy.

Umar and Bakar (2016) using an autoregressive distributed lag model, examine the short-run and long-run impact of arms importation on the economic growth in Nigeria. They recommend that defense R\&D as well as Defense Industrial Cooperation of Nigeria should be properly financed and managed for efficiency and self-reliability. Broude et al. (2013) examine the link between defence spending in Israel, its domestic DIB and the leading role of R\&D expenditure, concluding that the country's "macroeconomy has not benefited from defence spending". Dunne et al. (2007), focusing on the DIB development determinants, classify countries as producers and non-producers (importers) of defence equipment. They find that the extent to which a country will be an importer, or a domestic producer will depend on military spending, R\&D costs, export controls and the nature of regional arms races.

Given that Greece is a typical case of a country involved in an arms race (Andreou and Zombanakis, 2006), ${ }^{7}$ the economic impact of developing a sound DIB becomes an essential issue. In fact, Ploumis (2017) argues that the Hellenic DIB should be considered an integral part of the Greek national defence framework. Consequently, the ownership structure and management of major defence industrial enterprises should be reformed within the European framework. Furthermore, given that a sound DIB requires technology and skilled work force, the author suggests that Greek institutions of higher education should support this effort. A look at the Turkish case, the "partner" of Greece in their arms race, is enough to convince the reader on the contribution of a sound DIB to the economic growth of

\footnotetext{
${ }^{7}$ It has now been established in the literature that the Greek side is compelled to follow the Turkish defence procurement policy regardless its direction of change. It refers to earlier work on this issue (Andreou and Zombanakis, 2006) in which an arms race between the two sides has been established despite occasional objections (Brauer, 2002). The fact is, however, that the defence potential of Turkey has risen despite its recent economic problems. By contrast, the ability of Greece to build up a reliable defence industrial base continues to erode even after the end of the crisis in an investment-hostile economic environment.
} 
a country. It has been demonstrated repeatedly in the literature through a series of contributions starting with (Brauer, 2002) until recently, Demir et al. (2016), Mevlutoglu (2017), Kurç (2017), that the Turkish defence industry is prospering supplying a substantial percentage of the country's required defence material. In the case of Greece, however, since most of the defense equipment is imported, one cannot expect a positive impact on economic performance. On the contrary, according to Sezgin (2003) equipment defence spending entails adverse repercussions on the economic growth of Greece.

\section{A Glance on the Hellenic and the Turkish Defence Industries}

The Hellenic defence industry, except for one case (PYRCAL established in 1874) has been created mainly because of exogenous pressure applied after the 1974 Greek - Turkish clash rather than following a long-term planning procedure. The reasoning behind establishing a domestic defence industry was to relieve the Hellenic Armed Forces from constraints like dependence on foreign suppliers, substantial delivery delays, spare part shortage and considerable foreign exchange outflows. During the 1970s, the Greek government encouraged both public and private funds to promote defence industry. As a result, several essential production units begun to form the defence infrastructure of the country. Since then, however, the performance of these firms has left a lot to be desired in terms of efficiency and support of the armed forces requirements. This has been mainly due to serious weaknesses like mismanagement, strong political involvement, absence of coordination with the EMPAE, and the reluctance of the country's academic institutions to benefit from research and development (R\&D) programmes as well as technology transfer. Such weaknesses introduced market distortions and lead to the disorientation of these industries from leading targets like profit maximisation.

As a result, the Hellenic DIB currently supports only a negligible percentage of the Hellenic Armed Forces equipment requirements (Brauer, 2002; ELIAMEP, 2007; Andreou et al., 2013). The situation seems to have deteriorated since the beginning of the economic crisis, with the reduction of the resources allocated to defence projects, the absence of specialized technical and administrative personnel, as well as the restrictions imposed on the use of patents and the technical production documents (TPD) owned by the original equipment manufacturers (OEM) (Andreou et al., 2013). This environment is certainly inadequate to contribute to the maintenance and support of the Hellenic Armed Forces equipment ${ }^{8}$ and has inevitably compelled the Hellenic Armed Forces to resort to extensive expenditure

\footnotetext{
${ }^{8}$ A notable exception in this environment of inadequacy seems to be the Hellenic Aerospace Industry (HAI), which supports the depot - level maintenance (DLM) of the entire fleet of flying NATO Radar. The recent history of the HAI cooperation with NATO involves 279 maintenance and 750 units of engines components.
} 
on imports of equipment that can guarantee their readiness. This means that the defence of the country continues to rely heavily on foreign suppliers, while such an environment hardly contributes to the country's economic growth, unemployment containment and balance of payments sustainability.

In fact, this is the point that this paper aims at tackling i.e., the extent to which placing emphasis on domestic production rather than imports of defence equipment is expected to contribute to the benefit of the Greek economy in more than one way. Indeed, we argue that the more the government opts for promoting procurement from domestic sources at the expense of imports, the more it contributes to growth and employment. It also relieves the balance of payments from its sustainability constraint, given that in such a case the payments involved are not recorded in the external trade flows of the country according to the resident - non-resident criterion (IMF, 2009). Finally, yet importantly, such a policy is expected to contribute to the integration of the Greek industrial complex to the European industry with all the benefits that the resulting technology transfer may entail in such cases.

Contrary to the case of Greece, Turkey embarked in the process of building up a sound DIB as early as in 1920s, following the setup of the General Directorate of Military Facilities and the establishment of a group of repair facilities for weapons and ammunition, aiming at supporting the needs of the national ground armed forces. The naval dimension was introduced with the setup of the Gölcük Shipyard a few years later and subsequently followed by the Turkish aviation industry established in 1926. Again, unlike Greece in the case of which the Cyprus crisis was a beginning of simply changing defence equipment imports from the US to Europe, Turkey regarded the arms embargo imposed on her as the need to promote its national defence industry in order to avoid its dependence on foreign supply, resorting to import substitution (Durmaz, 2014).

Thus, under the auspices of the Presidency of Defence Industries (SSM) has proceeded with modernizing the industry aiming at technology transfer and export promotion. Concerning the first target, this seems to have been attained to a considerable extent (Gumus et al., 2009). Regarding export promotion, however, current export figures do not promise a significant growth in the near future (Mevlutoglu, 2017). As the author points out, further increase in export sales "will only be possible through more emphasis on $R \& D$, innovation, and sound business development strategies". Despite such problems, however, the Turkish defence industry supports a considerable percentage of the national armed forces requirements, thus contributing to the growth of the economy ${ }^{9}$.

\footnotetext{
${ }^{9}$ Côrte Réal-Pinto Anouck Gabriela. (2017). A Neo-Liberal Exception? The Defence Industry 'Turkification' Project. Revue internationale de politique de développement. 8. 10.4000/poldev.2316.
} 


\section{Data and Methodology}

The data covers the period 1970-2019. Following Broude et al. (2013), we tend to agree that "the impact of the military on the economy is best modelled in terms of a simultaneous equation model (SEM), which in turn should reflect the predominant structural characteristics of the economy" 10 . We thus, use a simultaneous equation system (SES) consisting of three equations for each of the two countries that explain GDP growth, government spending and defence expenditures designed to underline the links between defence spending and economic growth. In fact, what we seek to show is that contrary to the point made by Aizenman and Glick (2006) and unlike the case of Turkey, defence spending exerts a negative impact on the Greek economic growth in the presence of threat given that the majority of the defence equipment used is imported ${ }^{11}$.

The reformulation of the Barro (1990) model used by Aizenman and Glick (2006), which allows for security effects on output seems potentially more promising. Security is measured by military expenditure relative to the threat and this produces a non-linear effect of military expenditure. Military expenditure has a positive effect on output when the threat is high and a negative effect when threat is low. In refining growth models to allow for such non-linearities, defence economists have a comparative advantage since in estimating demand for military expenditure functions they have obtained considerable experience in measuring threats and other factors that influence military expenditures. Thus, there is a theoretical as well as an econometric reason for estimating simultaneous systems that explain both military expenditures and output (Dunne et al., 2005).

The use of a SES rather than a single growth equation solves the problem of simultaneity bias since growth, investment and defence spending tend to be determined simultaneously. As Broude et al. (2013) point out, this framework "accounts for both demand and supply side factors whereby the military sector is not only an input into the production function but also creates aggregate demand and thus induces the underemployed economy towards its production possibility frontier".

As the paper focuses on the defence sector of the two countries, this issue requires special emphasis. Since defence expenditure affects growth through a variety of channels a structural model should be able to capture some of them (Deger and Sen, 1995). Such channels are the resource allocation effect by which an increase

\footnotetext{
${ }^{10}$ Such models may be quite elaborate, but data availability predicates that we keep these models relatively simple.

${ }^{11}$ The Aizenman and Glick (2006) model suggests that military expenditure induced by external threats should increase output, by increasing security; while military expenditure induced by rent seeking and corruption should reduce growth, by displacing productive activities. The empirical results later in our paper underline the validity of this argument.
} 
in defence may crowd out investment or increases in other forms of government expenditures, which in turn may reduce national savings. Thus, defence expenditure is shown to affect the remaining public spending items, which, in their turn, determine the growth of the economy. The demand for defence expenditure function follows the well-established theoretical background (Smith 1980 and 1989) with the defence spending on equipment added to the determinants. This modification has proven to be successful (Bragoudakis and Zombanakis, 2017; Katsaitis et al., 2019) for several reasons: First, it avoids double counting in cases in which variables representing the total national budget are included in the model $^{12}$. The second reason is that focusing on the defence equipment emphasizes on the technical progress embodied in it and the ensuing stimulating effects on private investment in R\&D (Kennedy, 1987; Herrera and Gentilucci, 2013). The fact that in the case of Greece the bulk of the defence equipment is imported using the specific variable underlines the failure to profit from such technological benefits. The model is given as follows:

$$
\begin{aligned}
& G D Y=c_{1}+c_{2}(G G S-G D E F)+c_{3} G G K+c_{4} G S S+c_{5} G E Q D E F_{-4} \\
& (G G S-G D E F)=c_{6}+c_{7} G D E F+c_{8} G K K_{-1}+c_{9} G P O P \\
& G D E F=c_{10}+c_{11} G E Q D E F+c_{12} T D E F+c_{13} S P_{-1} \\
& T D Y=c_{14}+c_{15}(T G S-T D E F)+c_{16} T G K+c_{17} T S S+c_{18} T E Q D E F_{-4} \\
& (T G S-T D E F)=c_{19}+c_{20} T D E F+c_{21} T P O P T \\
& T D E F=c_{22}+c_{23} T E Q D E F+c_{24} G D E F+c_{25} S P_{-4}
\end{aligned}
$$

where: $D Y$ is GDP growth while $G S$ stands for total government spending. $D E F$ represents defence spending, $G K$ gross capital formation and $S S$ savings. EQDEF stands for defence spending on equipment and POP denotes population growth. Finally, the DEF variable of Greece or Turkey represents the threat to the arms race "partner's" defence spending in equations (6) and (3) respectively, while $S P$ stands for the NATO defence spending spillover benefits because of each country's NATO membership. $G S, D E F, G K, S S$ and $E Q D E F$ are measured as percentages of GDP. The prefix G or T denotes whether the variable refers to Greece or Turkey, respectively. All variable sources are presented in Table A2, in the Appendix.

Equations (1) and (4) describe GDP growth, equations (2) and (5) non-defense government spending and equations (3) and (6) constitute a modified typical demand for defence expenditure equation. More specifically, the growth and government spending equations (1), (2), (4) and (5) follow Ram (1995) and Deger and Sen (1995). Savings and non-defence government spending determine

\footnotetext{
${ }^{12}$ More specifically, the defence expenditure for salaries and pensions of the military and civilian personnel are included in both the total defence spending figures and the state budget. Thus, substituting defence spending on equipment for the total defence spending avoids such double counting issues. For similar problems refer to Torres (2020).
} 
economic growth, while non-defence government spending is a function of defence expenditure, gross capital formation and population growth. The defence expenditure equations (3) and (6) rely heavily on the latest developments concerning Greek - Turkish relations and use the standard explanatory variables. The pronounced presence of defence expenditure in the growth and government spending equations is justified by the fact that national security (as this is approximated by defence expenditure) is a public good. The focus of this paper, however, requires that we treat defence spending on equipment as a distinct variable to underline its adverse effect on the GDP growth in cases in which the Armed Forces requirements are met by importables. Finally, equations (2) and (5) which determine the non-defence government spending in both countries use a dummy variable each to capture the effect of the crisis years in the case of Greece and the return to constitutional law in the case of Turkey, following the 1980 military coup.

As far as the signs of the coefficients of the explanatory variables are concerned, we expect non-defence government expenditure, gross investment, and savings to contribute to growth thus bearing a positive sign. By contrast, to the extent that defence spending on equipment represents importable, it brings about a negative influence on the rate of growth. Furthermore, we expect the total defence spending crowds out the non-defense component of government expenditures and therefore exhibit a negative relationship to it, unlike the population growth, which usually demands an increase in government spending. Finally, all arguments of the demand for defence spending equation are expected to have a positive sign (Sandler and Hartley, 1995).

Given the formulation of the system above, endogeneity may clearly be an issue, thus the model is estimated using General Method of Moments (GMM). The major advantage of GMM is that its estimates can be robust to heteroscedasticity and distributional assumptions (Hansen and Singleton, 1982). The system is estimated using the heteroscedasticity and autocorrelation robust variance-covariance matrix of Newy-West. As instruments, we use the demeaned variables squared lagged once and the product of the variables taken two at a time.

\section{Empirical Results}

Table 1 presents the GMM coefficient estimates. They are all highly significant given their t-statistics and bear the expected signs. An extra dividend of using the GMM is the J-statistic, i.e., the value of the objective function times the number of observations. The $\mathrm{J}$ statistic is distributed as a $X^{2}$ distribution with degrees of freedom equal to the number of instruments minus the number of parameters. The J statistic provides us with an encompassing test for testing the validity / no misspecification of the model. The value of the $\mathbf{J}$ statistic for this model is 0.98 , thus the hypothesis of misspecification can be rejected at any reasonable level of 
confidence. Furthermore, the residuals do not exhibit any autocorrelation (See Table A1 in the Appendix).

Given the importance of our results for designing and assessing economic policy, we utilize an extra test to assess whether our estimates are, at least, consistent. We estimate the model using 3SLS. The estimates are in principle consistent, however, relatively inefficient compared to GMM. Table A3 in the Appendix presents the parameter estimates for the 3SLS. As expected, they are close to the ones obtained by GMM, but standard errors are larger.

Turning to discussing the values derived for the coefficients in focus and bearing in mind that the scope of the paper is to trace the link between defence expenditure and the GDP growth in both countries, we start with equations (3) and (6) in which the expenditure on defense equipment increases the total defence spending of each country as expected. The corresponding arc elasticities derived for the determinants of defense expenditure (Table 2) are to a large extent within the range of those reported in the literature (Brauer 2002). Equations (2) and (5) show how the rise of defence spending following increased defence payments crowds out non-defence government expenditure due to the imposed fiscal constraint. In the Greek case, given the positive relation between non-defence government spending and the GDP growth in equation (1) what is expected is a consequent reduction of the growth rate, which traces back to the effect brought about due to the imports of defence equipment.

It is interesting to observe, in this case, that in both countries the impact exercised by defence equipment procurement is imposed on the GDP growth via two channels. The first is the impact exercised following the reasoning just described and the second is the "direct" adverse effect, as imports of defence equipment enter equations (1) and (4) directly with a negative $\operatorname{sign}^{13}$. This is a reasoning suggested

\footnotetext{
${ }^{13}$ As earlier pointed out, the Aizenman and Glick (2006) conclusion seems to fit the case of Greece, a country facing external threats. Thus, while Greek output should be expected to increase via military expenditure, the results derived point to a negative effect of the defence spending on growth due to the prevailing corrupt environment with several related cases brought to justice and a number of high officials imprisoned. Despite recent efforts to privatisation aiming at improving the efficiency of a certain number of firms, the fact remains that the Hellenic defence industrial base as it stands can only meet a small percentage, possibly around 10\% of the country's procurement needs in value terms as these are expressed in the medium and long term EMPAE while the rest is imported (ELIAMEP, 2007). This means that the defence of the country continues to rely heavily on foreign suppliers whose local agents are most happy to collect their commission fees for promoting business mainly via the so called "military offsets", the value of which in some cases may even exceed 100\% of that representing the initial agreement. It appears, however, that the use of such offsets is far from being fruitful for the Greek side, given that the legal framework underlying their application is full of "grey areas" leaving ample room for personal interpretation (ELIAMEP, 2007).
} 
by Yakovlev (2007) indicating that "if a country hopes to lose less in economic growth from an additional military spending, it better be a net arms exporter". This finding stresses the problem faced by Greece, a country that, unlike Turkey, is far from being an arms exporter! Needless to point out that defence equipment procurement enters the growth equations of both countries with a four-year time lag to account for the usual revisions of the medium-term procurement programs in each of the two countries.

As expected, the inverse relationship between defence spending on equipment and growth holds in the case of Turkey as well as shown in equation (4). However, unlike the case of Greece in which non-defence government expenditure exercises a positive effect on growth, this is not the case with Turkey. This is a finding, which must be considered in connection to the fact that the government size and consequently government spending in Turkey is too high and that the economy may grow at a faster rate to the extent that it can be relieved of some of the government burden (Mitchell, 2005).

\section{Policy Implications}

Solving the system of equations (1) to (6) for the six endogenous variables for both countries and with the help of the arc elasticities recorded in Table 2, one can reach a number of interesting policy implications and conclusions concerning the role of the domestic defence industrial base in the two countries. The first finding concerns the direct impact of the defence equipment procurement on the growth rate of both countries as this appears in equations (1) and (4) which is negative in both cases, meaning that defence equipment purchases exert an adverse impact on both countries' GDP. This is a finding which should be expected given that defence spending on equipment is to a large extent imported and consequently deprived the economy of valuable resources. The difference lies with the fact that in the Greek case the response of the growth rate to defence equipment purchases reveals an elastic behaviour as opposed to an inelastic one in the Turkish case. ${ }^{14}$ Again, this is expected, given that about $70 \%$ of the Turkish defence equipment requirements are domestically produced ${ }^{15}$, while in the case of Greece tis percentage has always been a one-digit figure.

The second finding traces the indirect impact of spending on defence equipment on the growth rate of the two countries. Following a chain reaction, (equations 1 to 3

\footnotetext{
${ }^{14}$ The arc elasticities of growth with respect to defense spending on equipment, shown in Table 2, were estimated based on the coefficients derived from the solution of the system. ${ }^{15}$ https://carnegie-mec.org/sada/82936. https://www.gbreports.com/wp-content/uploads/2016/03/Turkey-Aerospace-2016-OnlineVersion.pdf.
} 
for Greece and 4 to 6 for Turkey) the defence equipment procurement increases the total defence spending and this, in its turn, crowds out non-defence public spending in both countries, something which affects their rate of growth. It is interesting to observe, however, that while in both countries, the indirect impact of defence equipment purchases on their growth rate is inelastic, in the case of Greece this impact is adverse while this is not so in the case of Turkey in which the final impact is positive.

Turning to the essence of the paper, which is the assessment of the equipment procurement impact on the economic growth of Greece and Turkey, we shall embark on a straightforward exercise based on the GMM solution of the model and the coefficient estimates derived. This exercise concerns the requirements of the Greek armed forces ${ }^{16}$ in view of the Greek-Turkish arms race and the increasing pressure exercised by Turkey for "lebensraum" in the Aegean and East Mediterranean:

As things stand now, Greece spends a rough $2.5 \%$ of its GDP to its defence needs, including wages, salaries, and pensions of the military and civilian personnel. Given that the Greek GDP is in the range of $€ 200$ bill, the sum devoted to total defence spending will be about $€ 5$ bill. Out of this only about $10 \%$, that is $€ 500$ mil. will be channelled to defence equipment procurement, most of which will be imported, given the poor performance of the Hellenic DIB ${ }^{17}$. Such levels of defence expenditure are obviously inadequate to finance the programmes aiming at replacing at least some of the old Standard - type frigates of the Hellenic Navy, designed to patrol in the wider East Mediterranean.

What Greece needs to start with, therefore, is to increase the equipment defence spending to about $€ 1$ bill per year as recent research points out (Katsaitis and Zombanakis, 2020). In fact, the Hellenic Navy will need two frigates to be employed in the Eastern Mediterranean, while the Hellenic Air Force will require substantial reinforcement. ${ }^{18}$. The cost of both programmes exceeds $€ 4$ billion which if distributed evenly throughout the next four-year procurement programme will mean that the "bill" devoted to defence procurement for next year will be of the order of $€ 1$ billion, i.e., double that for the current year in absolute

\footnotetext{
${ }^{16}$ Prime Minister's speech $<$ Thessaloniki, October, 2020

${ }^{17}$ To show the extent to which this is a sum far from being adequate to cover just the urgent operational needs of the Hellenic Armed Forces one needs to bear in mind that $30 \%$ of this amount, $i$. e. $€ 150$ mill, will be devoted to buying Seehecht torpedoes for the new T-214 submarines. The remaining $€ 350$ mill is demonstrably inadequate to finance the purchase of a Belh@ rra frigate for the Hellenic Navy!

${ }^{18}$ The contract for the procurement of 18 Rafales has been signed in January 2021 between France and Greece while an extensive F-16 modernization programme to the Viper version is already under way. (Greek Parliament, January 13, 2021).
} 
figures ${ }^{19}$.According to the model used, the options that Greece faces range from either importing the entire defence equipment, or, alternatively, to producing some of it domestically, to the best possible extent. Given the elasticities in Table 2 the first option is prohibitive due to the enormous cost that it entails in terms of GDP growth rate. By contrast, restricting imports to the extent that import substitution policies allow, and embarking on producing the remaining items at home is expected to result to a minor GDP rate reduction, a much more interesting option, as domestic defence production is anticipated to contribute to GDP growth. The problem lies with the fact that, due to the inadequacy of the Greek DIB to engage in contracts involving high $\mathrm{R} \& \mathrm{D}$ content the import substitution extent will be limited.

The situation in the case of Turkey, on the other hand, is by far better as shown in Table 2. For reasons of comparison, we shall assume that the defence spending on equipment procured will double, as in the case of Greece. Again, considering the elasticities of Table 2 there will be a direct adverse impact on the GDP growth rate to the extent that defence procurement is based on imports. Thus, the burden on the Turkish GDP growth rate is expected to suffer a slight decline as opposed to a prohibitive burden in the case of Greece, given that, as earlier pointed out, only high technology components are imported while most of the Turkish defence requirements are domestically produced. This means that a shift to emphasize on the domestic defence industrial base, by contrast, not only will avoid a GDP decline but, instead, it is expected to bring about a modest increase of the rate of GDP growth as shown by solving the system of equations 4 to 6 . Thus, thanks to the extensive development of the Turkish DIB, the impact on the growth rate of an import substitution policy regarding defence procurement is expected to be supportive.

\section{Conclusion}

Our paper aims at assessing the impact of alternative procurement policies on the Greek and Turkish growth rate: Imports versus domestic production. As expected, the adverse impact on the growth rate in both countries increases the more defence procurement relies on imports. In cases in which import substitution tactics are followed, such an adverse impact is much more tolerable. The extent to which this is the case depends on the development of the DIB in the two countries involved.

Focusing on the case of Greece, relying heavily on defence equipment imports is an option that the Greek economy recovering from a lengthy economic crisis and currently facing the COVID-19 pandemic cannot afford. These circumstances

\footnotetext{
${ }^{19}$ These calculations do not include the impact on the GDP following the COVID-19 virus pandemic which is expected to make things much worse in terms of defence burden on the GDP.
} 
provide policymakers the opportunity to learn from mistakes made in the past and to consider revising their priorities. In fact, the coincidence of the COVID-19 pandemic, together with the urgent needs for modern defence equipment in view of the instability in the Aegean and the Mediterranean dictate the following bitter lesson: Basing growth solely on services, boasting that "tourism is the heavy industry of our economy" is a blunder due to the high volatility of services receipts. By contrast, promoting a sound industrial base makes the economy much less vulnerable to external, unpredictable shocks. So much more if the industrial base is considerably defence-oriented, being an "economically strategic industry characterized by decreasing per unit costs reflecting economies of scale and learning, high technology reflected in major and costly $\mathrm{R} \& \mathrm{D}$, together with technical spillovers to the rest of the economy" (Sandler and Hartley, 2007). Apart from such purely economic benefits, emphasis on a domestic DIB would lead to self-sufficiency, immediate response in cases of emergency or even war and less dependence on foreign suppliers. It is certain that the Greek political nexus regrets its negligence to build a sound Hellenic defence industrial base in view of the volatile geopolitical environment faced today. This blunder has now compelled the country to embark on endless negotiations to lease frigates that should be ready and operational by now, to support the country's interests in the Aegean and the Eastern Mediterranean!

\section{Appendix:}

Table A1. System Residual Portmanteau Tests for Autocorrelations GMM

\begin{tabular}{cccccc}
\hline \hline Lags & Q-Stat & Prob. & Adj Q-Stat & Prob. & Df \\
\hline \hline 1 & 48.75733 & 0.0761 & 49.89122 & 0.0617 & 36 \\
2 & 80.26516 & 0.2360 & 82.89942 & 0.1785 & 72 \\
3 & 105.9541 & 0.5377 & 110.4680 & 0.4161 & 108 \\
4 & 138.1639 & 0.6214 & 145.8988 & 0.4401 & 144 \\
5 & 182.1910 & 0.4403 & 195.5704 & 0.2024 & 180 \\
6 & 218.8866 & 0.4324 & 238.0600 & 0.1448 & 216 \\
7 & 256.9766 & 0.4013 & 283.3562 & 0.0850 & 252 \\
8 & 288.5630 & 0.4796 & 321.9619 & 0.0822 & 288 \\
9 & 311.8834 & 0.6757 & 351.2789 & 0.1425 & 324 \\
10 & 329.2090 & 0.8764 & 373.7003 & 0.2984 & 360 \\
11 & 353.2183 & 0.9400 & 405.7128 & 0.3572 & 396 \\
12 & 377.9037 & 0.9713 & 439.6551 & 0.3891 & 432 \\
\hline \hline
\end{tabular}

Source: Own study. 
Table A2. Variable Sources*

\begin{tabular}{|c|c|}
\hline Total government spending & $\begin{array}{c}\text { World Bank national accounts data, and OECD National } \\
\text { Accounts data files. }\end{array}$ \\
\hline Gross savings & $\begin{array}{c}\text { World Bank national accounts data, and OECD National } \\
\text { Accounts data files. }\end{array}$ \\
\hline Gross Capital Formation & $\begin{array}{c}\text { World Bank national accounts data, and OECD National } \\
\text { Accounts data files. }\end{array}$ \\
\hline $\begin{array}{c}\text { Defence Spending on } \\
\text { Equipment }\end{array}$ & \begin{tabular}{c} 
Defense spending on equipment, NATO data base \\
\hline Total Defence Spending
\end{tabular} \\
\hline Population Growth & Total defense spending NATO data base \\
\hline GDP growth & World bank database \\
\hline NATO defence spending & FRED \\
\hline
\end{tabular}

Note: *Adding a prefix of $G$ or $T$ to the variable names above shows reference to Greece or Turkey respectively.

Source: Own study.

Table A3. 3SLS Coefficient Estimates

\begin{tabular}{|c|c|c|c|c|c|}
\hline $\begin{array}{c}\text { Equation Nr. \& } \\
\text { Determinants }\end{array}$ & \multicolumn{2}{|c|}{ Greece } & $\begin{array}{c}\text { Equation Nr \& } \\
\text { Determinants }\end{array}$ & \multicolumn{2}{c|}{ Turkey } \\
\hline$(1)(\mathrm{GDY})$ & $\begin{array}{l}\text { Coefficie } \\
\mathrm{nt}\end{array}$ & $\begin{array}{c}\mathrm{t}- \\
\text { statistic }\end{array}$ & (4) (TDY) & $\begin{array}{c}\text { Coefficie } \\
\mathrm{nt}\end{array}$ & $\begin{array}{c}\mathrm{t}- \\
\text { statistic }\end{array}$ \\
\hline$G G S-G D E F$ & 0.14 & 2.03 & $T G S-T D E F$ & -0.87 & -3.32 \\
\hline$G G K$ & 0.49 & 5.06 & $T G K$ & -1.64 & -4.36 \\
\hline$G S S$ & 0.81 & 2.89 & $T S S$ & 2.36 & 5.94 \\
\hline$G E Q D E F(-4)$ & -5.53 & -3.18 & $T E Q D E F(-4)$ & -2.13 & -1.51 \\
\hline & & & $(5)(T G S-$ & & \\
$(2)(G G S-G D E F)$ & & & TDEF) & & \\
\hline$G D E F$ & -8.91 & -10.17 & $T D E F$ & -0.91 & -3.02 \\
\hline$G G K(-1)$ & -0.72 & -6.67 & & & \\
\hline$G P O P$ & 9.43 & 4.56 & $T P O P T$ & $9.94 * \mathrm{e}-$ & 0.8 \\
\hline$(3)(\mathrm{GDEF})$ & & & $(6)(\mathrm{TDEF})$ & & 5.86 \\
\hline$G E Q D E F$ & 1.71 & 2.33 & $T E Q D E F$ & 1.00 & 5.37 \\
\hline$T D E F$ & 0.14 & 1.37 & $G D E F$ & 0.42 & 4.55 \\
\hline$S P(-1)$ & 0.13 & 1.93 & $S P(-4)$ & -0.02 & -0.33 \\
\hline$G D E F(-1)$ & 0.65 & 5.86 & $T D E F(-1)$ & 0.32 & 2.80 \\
\hline
\end{tabular}

Source: Own study. 


\section{References:}

Aizenman, J., Glick, R. 2006. Military Expenditure, Threats, and Growth. Journal of International Trade \& Economic Development, 15(2), 129-155.

Andreou, A., Zombanakis, G. 2006. The Arms Race between Greece and Turkey: Commenting on a Major Unresolved Issue. Peace Economics Peace Science and Public Policy, 12(1). http://www.bepress.com/peps/vol12/iss1/2.

Andreou, A., Migiakis, P., Zombanakis, G. 2013. On Defence Expenditure Reduction: Balancing between Austerity and Security in Greece. Peace Economics Peace Science and Public Policy. http://www.degruyter.com/view/j/peps.2013.19.issue3/peps-2013-0030/peps-2013-0030.xml?format=INT.

Barro, R.J. 1990. Government Spending in a Simple Model of Endogenous Growth. Journal of Political Economy, 98(5), 103-126.

Benoit, E. 1978. Growth and Defence in Developing Countries. Economic Development and Cultural Change, 26, 271-280.

Bragoudakis, Z., Zombanakis, A.G. 2017. Earning a Peace Dividend in a Crisis Environment: The Greek Case. Peace Economics, Peace Science and Public Policy. Available at SSRN: https://ssrn.com/abstract=3128214.

Brauer, J. 2002. Survey and Review of the Defence Economics Literature on Greece and Turkey: What Have We Learned? Defence and Peace Economics, 13, 85-107.

Broude, M., Deger, S., Sen, S. 2013. Defence, Innovation, and Development: The Case of Israel. Journal of Innovation Economics \& Management, 12(2), 37-57. doi:10.3917/jie.012.0037.

Deger, S., Sen, S. 1995. Military Expenditure and Developing Countries, in Handbook of Defence Economics, vol. 1, Hartley, K. and Sandler, T. (Eds). Amsterdam, North Holland.

Demir, K., Caymaz, E., Erenel, F. 2016. Defence Industry Clusters in Turkey. Journal of Defence Resources Management, 7(1), 7-20.

Dunne, P. 1995. The Defence Industrial Base, in Handbook of Defence Economics vol. 1, Hartley, K. and Sandler, T. (Eds). Amsterdam, North Holland.

Dunne, P., Haines, R. 2002. Defence Industrial Restructuring and Economic Growth in South Africa. Center for Real Economy Studies, TIPS.

Dunne, P., Smith, R.P., Willenbockel, D. 2005. Models of Military Expenditure and Growth: A Critical Review. Defence and Peace Economics, 16(6), 449-461. DOI: 10.1080/10242690500167791.

Dunne, P., García-Alonso, M., Levine, P., Smith, R. 2007 Determining the Defence Industrial Base. Defence and Peace Economics, 18(3), 199-221. doi: $0.1080 / 10242690600924273$.

Durmaz, M. 2014. The U.S. Arms Embargo of 1975-1978 and its Effects on the Development of the Turkish Defence Industry. Monterey Naval Postgraduate School,

ELIAMEP. 2007. Integrating Greece into the European Security Architecture: Greek Security Policy in the 21st Century.

Gumus, B., Demir, V., Kaynak, U. 2009. Technology Management in Turkish Defense Industry. PICMET '09 - 2009 Portland International Conference on Management of Engineering and Technology. Portland, OR, USA, 2905-2912. doi: 10.1109/PICMET.2009.5261782.

Hansen, L.P., Singleton, K.J. 1982. Generalized Instrumental Variables Estimation of Nonlinear Rational Expectations Models. Econometrica, 50, 1269-1286. 
Herrera, R., Gentilucci, E. 2013. Military Spending, Technical Progress, and Economic Growth: A Critical Overview on Mainstream Defense Economics. Journal of Innovation Economics and Management, 2013/2 ( $\left.{ }^{\circ} 12\right), 13-35$. DOI :

10.3917/jie.012.0013. URL: https://www.cairn.info/revue-journal-of-innovationeconomics-2013-2-page-13.htm.

IMF. 2009. Balance of Payments Manual, Sixth Edition.

IMF. 2010. Greece: First Review Under the Stand-By Arrangement. Country Report No. $10 / 286$.

IMF. 2012. Greece: Request for Extended Arrangement Under the Extended Fund Facility - Staff Report; Staff Supplement; Press Release on the Executive Board Discussion; and Statement by the Executive Director for Greece. Country Report No. 12/57.

IMF. 2014. Greece: Fifth Review Under the Extended Arrangement Under the Extended Fund Facility and Request for Waiver of Non observance of Performance Criterion and Rephasing of Access; Staff Report; Press Release and Statement by the Executive Director for Greece. Country Report No. 14/151.

Katsaitis, O., Kondylis, K., Zombanakis, G.A. 2019. Concerns on the Issue of Defence Expenditure in the Post-Crisis Greece. Security and Defence Quarterly, 24(2), 177-201. DOI: https://doi.org/10.35467/sdq/103408.

Katsaitis, O., Zombanakis, G. 2020. Reading between the Lines: A Cost Assessment of Friction between NATO Allies. In Wolfgang Peischel/Christoph Bilban (Eds.) Building Military Science for the Benefit of Society, International Society of Military Sciences, Carola Hartmann Miles-Verlag Berlin.

Kennedy, P. 1987. The Rise and Fall of Great Powers: Economic Change and Military Conflict from 1500 to 2000. New York, Random House.

Kuah, A., Loo, B. 2004. Examining the Defence Industrialization - Economic Growth Relationship: The Case of Singapore. Institute of Defence and Strategic Studies Singapore, Working Paper, No. 70.

Kurc, C. 2017. Between Defence Autarky and Dependency: The Dynamics of Turkish Defence Industrialization. Defence Studies, 17(3).

Mevlutoglu, A. 2017. Commentary on Assessing the Turkish Defence Industry: Structural Issues and Major Challenges. Defence Studies, 17(3).

Mitchell, D. 2005. The Impact of Government Spending on Economic Growth. Backgrounder, No. 1831.

Ploumis, M. 2017. Hellenic Defence Industrial Base in the Era of Economic Crisis. SouthEastern Europe Journal of Economics, 2, 103-125.

Ram, R. 1995. Defense Expenditure and Economic Growth. In Handbook of Defense Economics, vol. 1, 251-274, Elsevier.

Réal-Pinto, A.G.C. 2017. A Neo-Liberal Exception? The Defence Industry 'Turkification' Project. Revue Internationale de Politique de Développement. 8. 10.4000/poldev.2316.

Sandler, T., Hartley, K. 1995. The Economics of Defence. Cambridge U Press.

Sandler, T., Hartley, K. 2007. Handbook of Defence Economics. Cambridge U Press. Sezgin, S. 2003. Defence Expenditure and Economic Growth in Turkey and Greece: A Disaggregated Analysis. In Kollias, C., Günlük -Senesen, G. (Eds.) Greece and Turkey in the 21st Century: The Political Economy Perspective.

Smith, R.P. 1980. The Demand for Military Expenditure. The Economic Journal, 90(360), 811-820. 
Smith, R.P. 1989. Models of Military Expenditures. Journal of Applied Econometrics 4(4), 345-359.

Torres, J.L. 2020. The Production of National Defense and the Macroeconomy. PLOS, https://doi.org/10.1371/journal.pone.0240299.

Umar, A.M., Sufian, A., Bakar, A. 2016. The Interactional Impact of Defense Expenditure and Arms Importation on Economic Growth in Nigeria: An Autoregressive Approach. International Journal of Economics and Financial Issues, 6(2), 538-543.

Yakovlev, P. 2007. Arms Trade, Military Spending and Economic Growth. Defence and Peace Economics, 18(4), 317-338. 
Table 1. GMM Coefficient Estimates

\begin{tabular}{|c|c|c|c|c|c|}
\hline $\begin{array}{c}\text { Equation Nr. \& } \\
\text { Determinants }\end{array}$ & \multicolumn{2}{|c|}{ Greece } & $\begin{array}{c}\text { Equation Nr. \& } \\
\text { Determinants }\end{array}$ & \multicolumn{2}{c|}{ Turkey } \\
\hline$(1)(\mathrm{GDY})$ & Coefficient & $\begin{array}{c}\mathrm{t}- \\
\text { statistic }\end{array}$ & $\begin{array}{c}\text { (4) (TDY) } \\
\text { Coefficient }\end{array}$ & $\begin{array}{c}\mathrm{t}- \\
\text { statistic }\end{array}$ \\
\hline$G G S-G D E F$ & 0.17 & 12.15 & $T G S-T D E F$ & -0.34 & -6.64 \\
\hline$G G K$ & 0.45 & 21.67 & $T G K$ & -0.81 & -9.17 \\
\hline$G S S$ & 0.96 & 16.37 & $T S S$ & 1.18 & 11.77 \\
\hline$G E Q D E F(-4)$ & -4.16 & -9.76 & $T E Q D E F(-4)$ & -3.50 & -8.92 \\
\hline$(2)(\mathrm{GGS}-$ & & & & & \\
GDEF) & & & $(5)(\mathrm{TGS}-\mathrm{TDEF})$ & & \\
\hline$G D E F$ & -8.35 & -56.93 & $T D E F$ & -1.43 & -30.17 \\
\hline$G G K(-1)$ & -0.86 & -26.10 & & & \\
\hline$G P O P$ & 9.37 & 21.48 & $T P O P T$ & $6.92 * \mathrm{e}-0.8$ & 22.93 \\
\hline$(3)(\mathrm{GDEF})$ & & & $(6)(\mathrm{TDEF})$ & & \\
\hline$G E Q D E F$ & 0.68 & 14.06 & $T E Q D E F$ & 0.98 & 21.39 \\
\hline$T D E F$ & 0.05 & 3.32 & $G D E F$ & 0.34 & 18.07 \\
\hline$S P(-1)$ & 0.07 & 5.34 & $S P(-4)$ & -0.02 & -1.72 \\
\hline$G D E F(-1)$ & 0.79 & 47.45 & $T D E F(-1)$ & 0.42 & 14.47 \\
\hline
\end{tabular}

Source: Own study. 
Table 2. Impact on the Growth Rate of a $100 \%$ Increase of Defence Equipment Purchases*

\begin{tabular}{|c|c|c|}
\hline \multirow{2}{*}{ Equations } & \multicolumn{2}{|c|}{ Elasticity } \\
\cline { 2 - 3 } & Greece & Turkey \\
\hline $\begin{array}{c}\text { Direct Impact due } \\
\text { to EQDEF } \\
\text { (Equations 1 and 4) }\end{array}$ & $\mathbf{- 1 . 0 0}$ & $-\mathbf{0 . 1 3}$ \\
\hline Indirect Impact & & \\
\hline
\end{tabular}

Note: *Adding a prefix of $G$ or $T$ to the variable names above shows reference to Greece or Turkey, respectively. The underlying assumption for the calculations is that the import component of the defence procurement EQDEF is $90 \%$ for Greece and $30 \%$ for Turkey. Source: Own study. 